\title{
Amaranth Flour as a New Alternative Substrate for Schizophyllum Commune Fr.: Fr. and Cordyceps Sinensis (Berk.) Sacc. Growth
}

\author{
Tetiana A. Krupodorova* and Victor Yu. Barshteyn \\ Institute of Food Biotechnology and Genomics \\ of National Academy of Sciences of Ukraine \\ 2 a Osipovskogo str., Kyiv, 04123, Ukraine
}

Received 04.08.2014, received in revised form 21.09.2014, accepted 20.12.2014

The possibility of utilization of the waste after $\mathrm{CO}_{2}$-extraction of flour prepared from the Amaranthus hybridus L. grains (amaranth flour), as a medium for Schizophyllum commune Fr.: Fr. and Cordyceps sinensis (Berk.) Sacc. biomass production was explored. Biochemical analysis of amaranth flour was carried out. Basic components (moisture, protein, fat, ash, carbohydrates) of fungi mycelium were studied. Our results showed high biological efficiency of substrate utilization: $45 \%$ for Sch. commune and $29 \%$ for C. sinensis. We obtained $27.0 \mathrm{~g} / \mathrm{L}$ and $17.4 \mathrm{~g} / \mathrm{L}$ of mycelium of Sch. commune and C. sinensis, respectively, after 14 days of cultivation on amaranth flour. The fungal biomass of Sch. commune and $C$. sinensis can be consumed in food industry as a good source of main components: carbohydrates, dietary fiber, essential amino acids and unsaturated fatty acids.

Keywords: amaranth flour, fungi, mycelium, Schizophyllum commune, Cordyceps sinensis.

(C) Siberian Federal University. All rights reserved

* Corresponding author E-mail address: krupodorova@gmail.com 


\title{
Шрот амаранта - альтернативный суб́страт \\ для культивирования Schizophyllum commune Fr.: Fr. \\ и Cordyceps sinensis (Berk.) Sacc.
}

\author{
Т.А. Круподерова, В.Ю. Барштейн \\ Институт пищевой биотехнологии и геномики \\ Национальной академии наук Украинь \\ Украина, 04123, Киев, ул. Осиповского, $2 a$
}

Изучена возможность использования шрота амаранта (амарантовой муки) - побочного продукта $\mathrm{CO}_{2}$-экстракции семян Amaranthus hybridus L. - в качестве питательной среды для культивирования Schizophyllum commune Fr.: Fr. и Cordyceps sinensis (Berk.) Sacc. Проанализирован состав амарантовой муки, определены основные характеристики (влажность, белок, жир, зола, углеводы) мицелия грибов. Установлена высокая биологическая эффективность усваивания субстрата: 45 \% для Sch. comтипе и $29 \%$ для C. sinensis. Ha 14-е сутки поверхностного культивирования получено 27,0 и 17,4 г/л биомассы Sch. соттипе и C. sinensis соответственно. Биомасса грибов Sch. coтmипе и C. sinensis может быть использована в пищевой промышленности в качестве хорочего источника углеводов, пищевых волокон, незаменимых аминокислот и ненасыщенных жирных кислот.

Ключевые слова: амарантовая мука, грибы, мииелий, Schizophyllum coтmune, Cordyceps sinensis.

\section{Introduction}

Cordyceps sinensis (Berk.) Sacc. is an entomopathogenic fungus subphylum Ascomycotina, phylum Ascomycetes, class Pyrenomycetes, order Clavicipitales, and family Claviupitaceae (Kirk et al., 2008). It can be found in nature only at alpine pastures in north-west and central Himalayan region. Schizophyllum commune Fr.: Fr. belongs to the subphylum Basidiomycotina, phylum Basidiomycetes, class Basidiomycetes, order Agaricales, family Schizophyllaceae (Kirk et al., 2008) and is one of the most common bracket fungi with worldwide distribution. Both Sch. commune and $C$. sinensis are rich in biologically active compounds with potential therapeutic action and widely used as the components of nutraceuticals and functional foods. Thus, these fungi are important objects of biomedical research and trials: morphology, physiology, chemistry (Mizuno, 1999; Hsu et al., 2002; Chang, Miles, 2004; Chau, Wu, 2006; Cheung, 2008; Wasser, 2010). However, the knowledge of the nutritional value of the mycelium of these species is limited in comparison to composition of their fruit bodies. Qualitative and quantitative analysis of medicinal and edible fungi for the estimation of nutritional quality and biological activity is very important when they are used as foods or nutraceuticals (Cheung, 2008; Wasser, 2010). Besides this, the production of mycelium by solid-state or submerged fermentation is viewed as a promising alternative to fruit bodies. Biomass production by submerged 
fermentation has a number of advantages such as shorter period of cultivation and less chance of contamination. Usually, the culture medium for the higher fungi growth is mostly synthetic and semi-synthetic. The maximum values of biomass production and secondary metabolites of these fungi are presented in various reports (Jonathan, Fasidi, 2001b; Dong, Yao, 2005; Kumari et al., 2008; Smirnov et al., 2011). In addition, the reports describe natural monosubstrates for the mycelial cultivation. For example, a watersoluble homopolysaccharide can be produced by fermentation of Sch. commune on coconut water waste in submerged culture (Reyes et al., 2009). Amaranth flour is a waste after carbon dioxide extraction of Amananthus grains for oils and squalene (Matušovà, 2008). The amaranth oil is used in cosmetic products for skin and hair (e.g. face cream, shampoo, balsams). Amaranthus L. is a fast-growing agricultural culture, cultivated mainly on the American continent, many countries of Europe, Asia and Africa (Svirskis, 2003). Its unique composition attracts increasing attention of the world food industry: meat and dairy products, bakery, confectionary, instant food and noodles, sauce and mayonnaise, oils, children nutrition, biologically active additives etc.

The purpose of this work was to study Sch. commune and $C$. sinensis biomass production on amaranth flour in liquid culture under static condition and to investigate the chemical composition of the fungal mycelium.

\section{Materials and methods}

\section{Fungi species}

Schizophyllum commune Fr.: Fr. (Strain 1768) and Cordyceps sinensis (Berk.) Sacc. (Strain 1928) were obtained from the Culture Collection of Mushrooms (IBK) of the M.G. Kholodny Institute of Botany of the National Academy of Sciences of Ukraine (Buchalo et al., 2011).

\section{Cultivation medium basis}

The basis of cultivation medium was the waste after $\mathrm{CO}_{2}$-extraction of flour prepared from the Amaranthus hybridus L. grains (hereinafter referred to as amaranth flour). A. hybridus species was a variety «Ultra» (Mykolaiv Oblast, Ukraine, 2011). $\mathrm{CO}_{2}$-extraction conditions: pressure 7.2 $\mathrm{MPa}$; temperature $-24{ }^{\circ} \mathrm{C}$; duration of extraction -2 hours.

\section{Growth Conditions}

Mycelial cultures were initially grown in Petri dishes (90 $\mathrm{mm}$ in diameter) on culture medium, composed of (in $\mathrm{g} / \mathrm{L}$ ): glucose - 20, yeast extract - 3.0, peptone - 2.0, $\mathrm{K}_{2} \mathrm{HPO}_{4}$ 1.0, $\mathrm{KH}_{2} \mathrm{PO}_{4}-1.0, \mathrm{MgSO}_{4} \cdot 7 \mathrm{H}_{2} \mathrm{O}-0.25, \mathrm{pH} 6.0$ and then the mycelium was transferred to liquid cultivation medium contained $60 \mathrm{~g}$ of amaranth flour per $1 \mathrm{~L}$ of distilled water. The culture medium was sterilized by autoclaving for $20 \mathrm{~min}$ at $121^{\circ} \mathrm{C}$. Mycelium was grown as static cultures in 250 -mL flasks for 14 days at $26 \pm 2^{\circ} \mathrm{C}$.

\section{Separation}

Mycelium was separated from the medium by filtration through Whatman's filter paper № 4 and washed with distilled water. Then, it was high-vacuum freeze dried with a Cryodos-50 freeze dryer (Terrasa, Spain) and ground using a blade grinder.

\section{Macronutrients}

Dry samples were analyzed for chemical composition (moisture, crude protein, crude fat, ash) according to AOAC methods (AOAC, 1990). Total nitrogen was determined with the Kjeldahl's method (Pleshkov, 1976). The crude protein was calculated using the conversion factor 4.38 (Crisan, Sands, 1978). The content of amino acids was estimated with a T-339 amino acid analyzer ("Mikrotechna", Prague, Czech Republic) (Krischenko, 1983). 
Lipids were extracted by Folch's method (Folch et al., 1957), and fatty acids were estimated using a "Crystal Lux" chromatograph ("BIOMASHPRIBOR", Yoshkar-Ola, Russia) with flame-ionization detector on the capillary column SP-2560 (Supelco, USA). Fatty acids were presented as percentages of the total sum with precision up to $0.01 \%$.

Crude fibre was determined according to patent (Osadchenko, Gorlov, 2002).

Carbohydrates (\%) were calculated as follows (Grangeria et al., 2011):

$$
\text { Carbohydrates }=100-(\text { protein }+ \text { fat }+ \text { ash })
$$

The energy content was calculated with the following factors: protein $4.0 \mathrm{kcal} / \mathrm{g}$; fat 8.37 $\mathrm{kcal} / \mathrm{g}$ and carbohydrates $3.48 \mathrm{kcal} / \mathrm{g}$ (Crisan, Sands, 1978).

Biological efficiency (\%) was calculated using the following equation (Jwanny et al., 1995):

$$
\text { Biological efficiency }=\left(\frac{A}{B}\right) \cdot 100,
$$

where $A$ is weight of mycelium, $B$ is weight of amaranth flour in the medium.

\section{Vitamins}

Determination of vitamin $B_{1}$ was based on the oxidation of thiaminum to the thiochrome, extraction of residuum with an organic solvent and measuring of intensity of fluorescence (Ostrovsky, 1975).

Detection of vitamin $\mathrm{B}_{2}$ was carried out using riboflavin-binding apoprotein from egg albumin in accordance with method of Kondentsova (1994).

Vitamin $B_{12}$ was determined with the microbiological method (Bilay, 1982) by means of indicatory culture of Escherichia coli 113-2, which has a sensitiveness 0.005-5.0 $\mu \mathrm{g} / \mathrm{ml}$.
Vitamin A and carotenoids were determined with the colorimetric method based on reaction of antimony trichloride and trifluoroacetic acid (Ostrovsky, 1979).

Measuring of vitamin C (ascorbic acid) was based on its reductive properties in particular, the ability to recover potassium iodate to free iodine, which amount is determined by reaction with starch (Pleshkov, 1976).

\section{Chemical elements}

Chemical elements (Na, P, K, Ca, Ti, V, Cr, $\mathrm{Mn}, \mathrm{Fe}, \mathrm{Co}, \mathrm{Cu}, \mathrm{Zn}, \mathrm{As}, \mathrm{Zr}$, Mo, Cd, Ba, La, Hg, $\mathrm{Ti}, \mathrm{Pb}, \mathrm{Ce}$ ) were determined using the Thermo Scientific "Element-2" HP-ICP-MS ("Thermo Finnigan", Bremen, Germany) (Chudinov, 1990).

\section{Statistical analysis}

All experiments were carried out in triplicate. The data were analyzed by Excel statistical functions using Microsoft Office XP software the Statistical Package for Social Sciences, Program 11.5 Version (SPSS, Inc., 2002). Values are presented as means \pm standard error of the mean (SEM). Differences at $\mathrm{P} \leq 0.05$ were considered to be significant.

\section{Results and discussion}

The feasibility of using the agricultural waste, amaranth flour, as an alternative substrate for the cultivation of mycelium was investigated. The growth of fungi depends on the presence of a number of important nutrient substances in a substrate: carbon and nitrogen sources, protein, vitamins, macro- and microelements. Therefore, we investigated our potential substrate for the levels of biologically active constituents.

Amaranth flour used in this study contained $15.4 \%$ protein, $1.5 \%$ fat, $3 \%$ ash, $4 \%$ dietary fiber and $3.7 \%$ moisture (we have obtained these data for A. hybridus for the first time). The content of protein, fat and ash in amaranth flour 


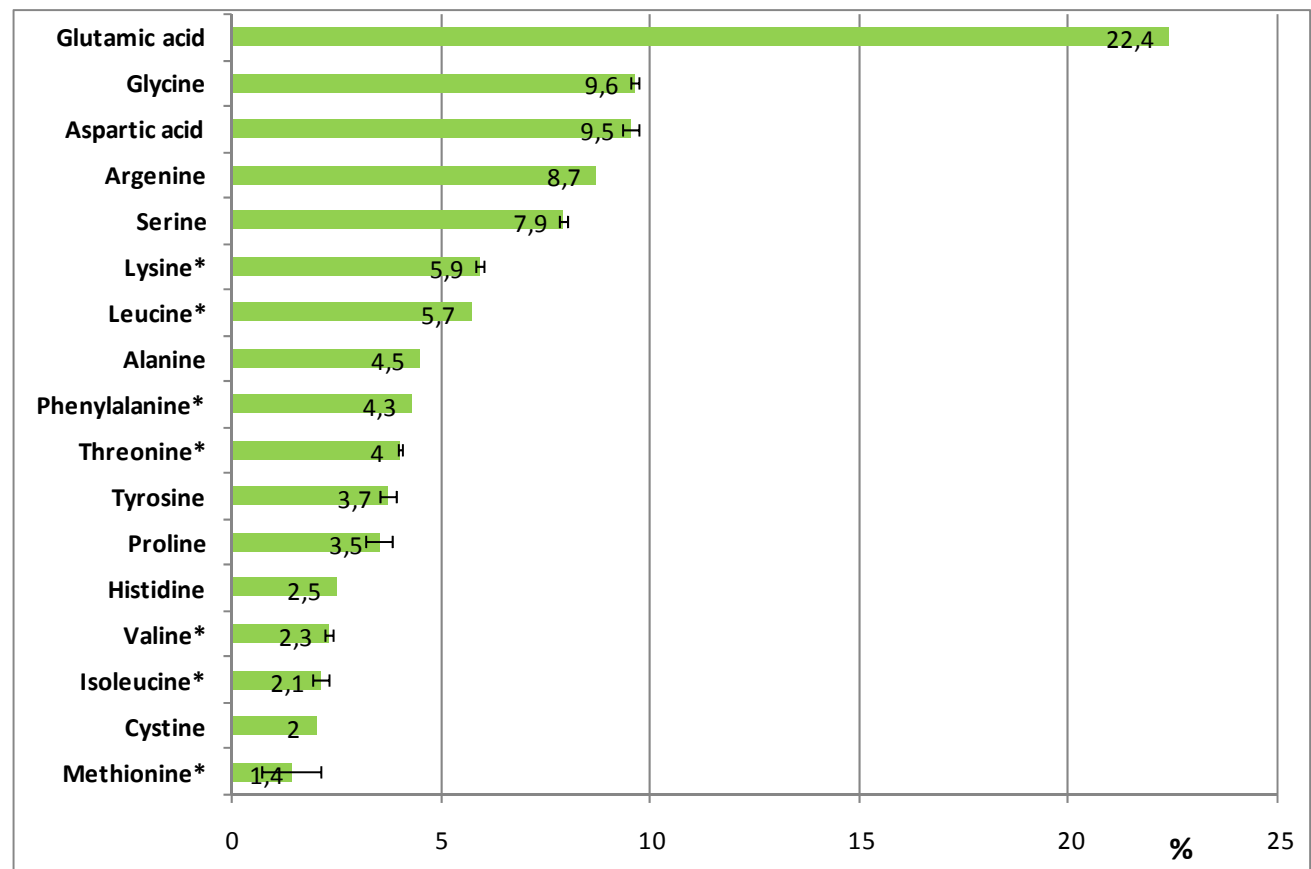

Fig. 1. Content of amino acids in amaranth flour ( $\%$ of the total), *essential amino acids, bars represent standard errors $(n=3)$

Table 1. Vitamin content in amaranth flour

\begin{tabular}{lc}
\hline \multicolumn{1}{c}{ Vitamins } \\
\hline Thiamine $\left(\mathrm{VB}_{1}\right), \mathrm{mg} / \mathrm{g} \mathrm{dw}$ & $0.5 \pm 0.1$ \\
Riboflavin $\left(\mathrm{VB}_{2}\right), \mathrm{mg} / \mathrm{g} \mathrm{dw}$ & not detected \\
Cyanocobalamin $\left(\mathrm{VB}_{12}\right), \mu \mathrm{g} / \mathrm{g} \mathrm{dw}$ & $0.1 \pm 0.0$ \\
Vitamin A, $\mathrm{mg} / \mathrm{g} \mathrm{dw}$ & trace \\
Carotenoids, $\mathrm{mg} / \mathrm{g} \mathrm{dw}$ & trace \\
Ascorbic acid, $\mathrm{mg} / \mathrm{g} \mathrm{dw}$ & $0.5 \pm 0.2$ \\
\hline
\end{tabular}

Each value is expressed as mean $\pm \mathrm{SE}(\mathrm{n}=3)$.

from Amaranthus cruenthus L. (Shmalko, 2005) hardly differed from our data, in contrast to fiber and moisture content.

Amaranth flour is rich in amino acids (Fig. 1). Amaranth flour contains a high amount of essential amino acids, such as lysine and leucine, and nonessential amino acids - glutamic acid, aspartic acid and glycine. This is important, given the results of numerous studies (Fasidi, Olorunmaiye, 1994; Jonathan, 2002; Gbolagade et al., 2006; Johnsy, Kaviyarasan, 2013; Neelam et al., 2013) that have shown that the addition of various amino acids promoted growth of higher fungi.

Five vitamins, mainly ascorbic acid, were found in amaranth flour (Table 1). A number of researchers have shown that vitamins contributed to the increased growth of mycelium. Addition of thiamine increased growth of $C$. sinensis mycelium by 1.2 times (Dong, Yao, 2005) and 
Sch. commune mycelium by 1.8 times (Jonathan, Fasidi, 2001b), addition of ascorbic acid increased growth of Sch. commune mycelium by 1.4 times (Jonathan, Fasidi, 2001b). Thiamine was the best stimulator of mycelial growth of Pleurotus florida (Adenipekun and Gbolagade, 2006). Effect of thiamine addition on biomass augmentation can be explained by its role as co-enzyme for several enzymes of intermediary metabolism. According to Adejoye et al. (2007), vitamin addition was not absolutely required for Sch. commune growth, since this fungus is able to produce the vitamins necessary for its growth. A similar conclusion was reached as a result of studies of Pleurotus tuberregium growth (Fasidi, Olorunmaiye, 1994).

Our study has shown that amaranth flour contains 4 macroelements and 14 microelements (Table 2). Potassium, calcium and phosphorus are necessary components for biosynthetic activity of mycelium. Neelam et al. (2013) indicated the importance of calcium, magnesium and potassium for the growth of Pleurotus ostreatus and $P$. eryngii. The same behavior was noted for P. tuber-regium (Fasidi, Olorunmaiye, 1994), Sch. commune (Jonathan, Fasidi, 2001b) and $P$. florida (Adenipekun, Gbolagade, 2006). Calcium and magnesium also provided the best growth of Psathyerella atroumbonata (Pegler) (Jonathan, Fasidi, 2001a). However, calcium had little effect on the growth of $C$. sinensis (Dong, Yao, 2005). Researchers attach great importance to such essential microelements as $\mathrm{Zn}, \mathrm{Mn}$ and $\mathrm{Cu}$ : zinc is a functional component of enzymes (Garraway, Evans, 1984; Dong, Yao, 2005; Jonathan, Fasidi, 2001b), manganese plays important role in TCA cycle, in ATP metabolism, and nucleic acid synthesis (Garraway, Evans, 1984) and copper is the complement of copper-containing proteins and enzymes, mainly redox ones. It should be noted that the harmful and dangerous ions of $\mathrm{Cd}, \mathrm{Hg}, \mathrm{Pb}$ and $\mathrm{As}$ were not present in amaranth flour.
We obtained $27.0 \pm 0.2 \mathrm{~g} / \mathrm{L}$ of mycelial biomass of Sch. commune and $17.4 \pm 0.1 \mathrm{~g} / \mathrm{L}$ of C. sinensis after 14 days of static cultivation on amaranth flour. Maximum biomass of these fungal species varies with fungal strains and with cultivation conditions (medium, temperature, $\mathrm{pH}$, phase of growth, culture duration). However, the biomass of Sch. commune in our experiment was higher than that reported earlier by other researchers who used different mediums: glucose-peptone (Maziero et al., 1999; Bolla et al., 2008), glucose-bacto yeast extract (Shu et al., 2005), optimized medium with sucrose (Kumari et al., 2008; Smirnov et al., 2011; Kumar, Singhal, 2011), glucose-yeast extract (Adejoye et al., 2009), glucose-based medium (Yogita et al., 2011). C. sinensis accumulated higher biomass values compared to those reported by Liang et al. (2009) at solid state cultivation on fermented rice and was identical to the results by Smirnov et al. (2009) in a shorter period of submerged cultivation on molasses-based medium. Biomass obtained in this study in static culture was lower than that obtained by other researchers (Dong, Yao, 2005; Kim, Yun, 2005; Cha et al., 2007) with submerged cultivation on rotary shaker.

Biological efficiency is one of the significant calculated indices for understanding the extent of substrate utilization by growing fungal cultures. Taking into account that we worked with vegetative mycelium of fungi, but not with their fruit bodies, our results showed high biological efficiency of substrate - $45 \%$ for Sch. commune and $29 \%$ for $C$. sinensis cultivation.

The evaluation of the nutritional quality of different fungal products for their specific use is necessary and important. The basic compositions of the two fungi were significantly different (Table 3). Carbohydrate, dietary fiber and protein were the main components. Sch. commune mycelium contained higher amount of protein (45.4\%) and dietary fiber (35.7\%), whereas $C$. sinensis 


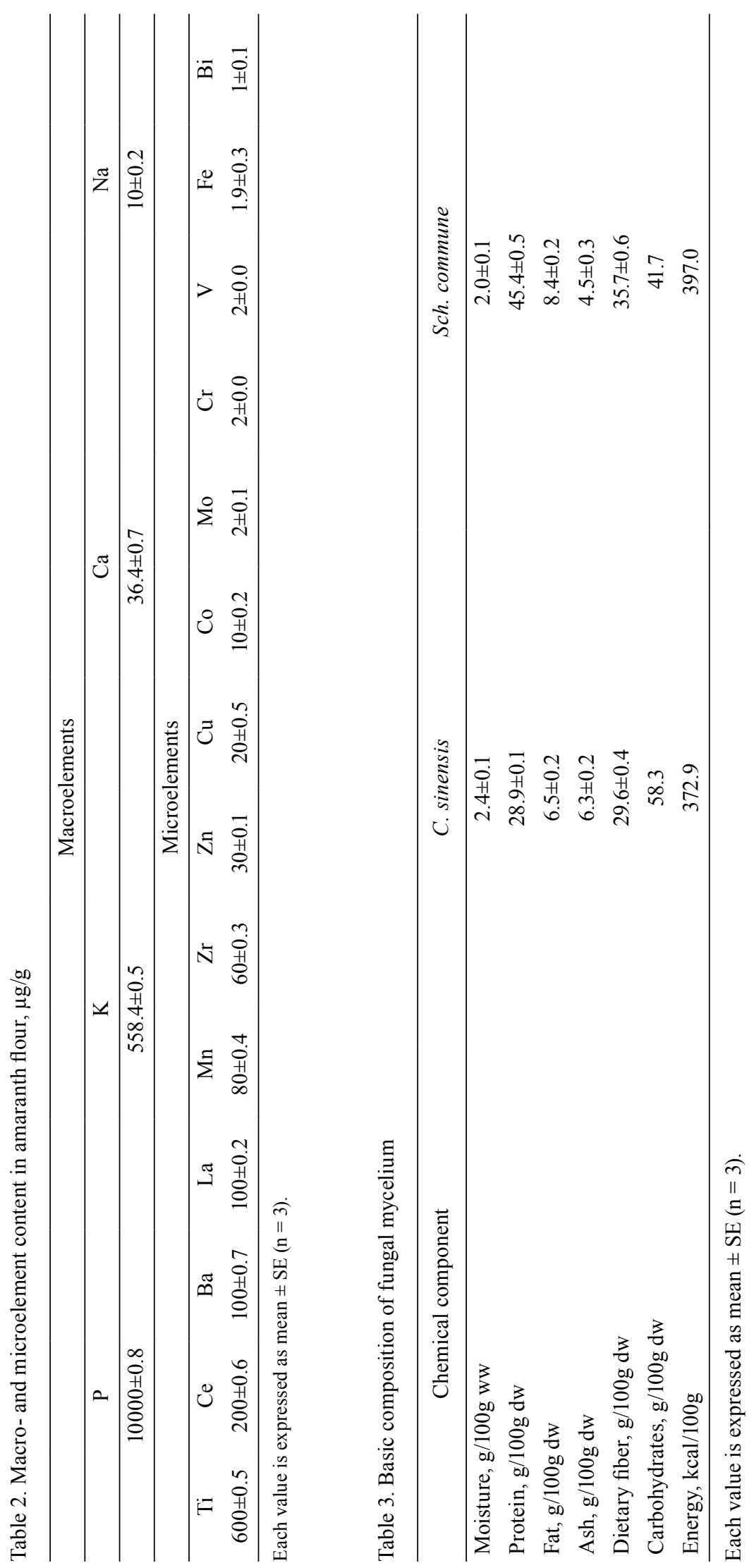




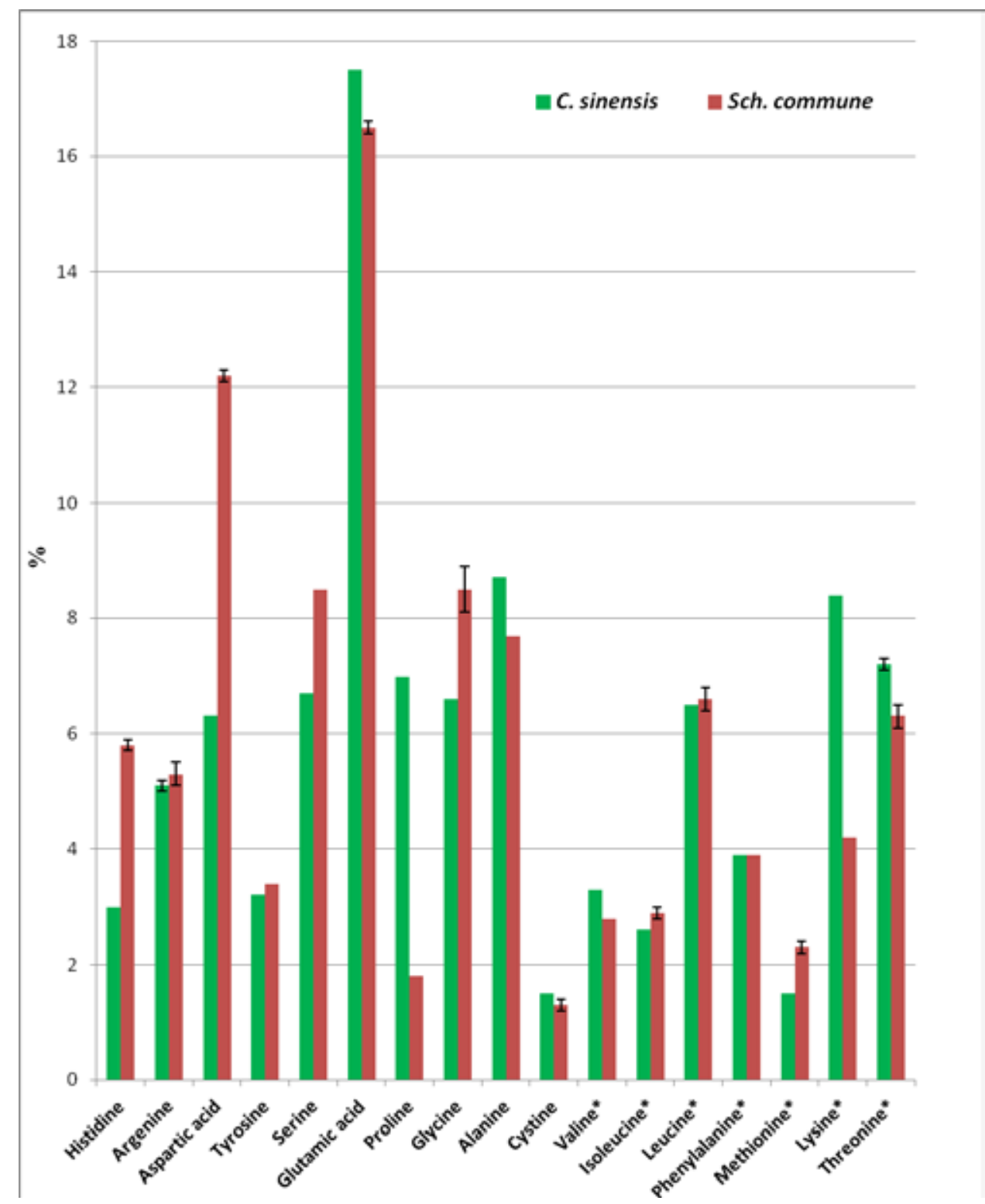

Fig. 2. Content of amino acids of fungal mycelia ( $\%$ of the total), *essential amino acids, bars represent standard errors $(n=3)$

mycelium was enriched with carbohydrate (58.3\%). The carbohydrate and dietary fiber content in mycelium of both fungi and protein content in Sch. commune mycelium were higher as compared to those reported by other researchers (Mizuno, 1999; Chang et al., 2001; Hsu et al., 2002; Tseng et al., 2005). The amount of protein in C. sinensis mycelium in our work is similar to that reported by Smirnov et al. (2009) and Mizuno (1999), but higher than the results of Hsu et al. (2002).

Fungal proteins of our species consisted of 17 amino acids, with glutamic acid predominating for both fungi (Fig. 2). Aspartic acid was high for Sch. commune, that's typical for other species of higher Basidiomycetes (Scherba et al., 1999; Babitskaya et al., 2003). Different numbers of 
Table 4. Content of fatty acids in fungal mycelium ( $\%$ of the total)

\begin{tabular}{|c|c|c|}
\hline Constituent & C. sinensis & Sch. commune \\
\hline C14:0 & $0.4 \pm 0.1$ & $0.6 \pm 0.1$ \\
\hline $\mathrm{C} 15: 0$ & $1.5 \pm 0.3$ & $1.3 \pm 0.2$ \\
\hline C16:0 & $16.4 \pm 0.2$ & $17.6 \pm 0.3$ \\
\hline $\mathrm{C} 17: 0$ & $0.5 \pm 0.2$ & $0.6 \pm 0.3$ \\
\hline C18:0 & $2.9 \pm 0.3$ & $1.4 \pm 0.1$ \\
\hline Saturated fatty acids & 21.7 & 21.5 \\
\hline C16:1 & $0.3 \pm 0.1$ & $0.2 \pm 0.1$ \\
\hline $\mathrm{C} 17: 1$ & $0.4 \pm 0.1$ & $0.3 \pm 0.1$ \\
\hline $\mathrm{C} 18: 1 \omega 9$ & $24.2 \pm 0.3$ & $21.1 \pm 0.5$ \\
\hline Monounsaturated fatty acids & 24.9 & 21.6 \\
\hline $\mathrm{C} 18: 2 \omega 6$ & $52.3 \pm 0.4$ & $55.8 \pm 0.4$ \\
\hline $\mathrm{C} 18: 3 \omega 3$ & $1.1 \pm 0.3$ & $1.2 \pm 0.1$ \\
\hline Polyunsaturated fatty acids & 53.4 & 57.0 \\
\hline Unsaturated fatty acids & 78.3 & 78.6 \\
\hline $\begin{array}{l}\text { Unsaturated fatty acids/ Saturated } \\
\text { fatty acids }\end{array}$ & 3.6 & 3.6 \\
\hline
\end{tabular}

Each value is expressed as mean $\pm \operatorname{SE}(n=3)$.

amino acids in $C$. sinensis mycelium are reported: 16 by Hsu et al. (2002), 17 by Smirnov et al. (2009), and 18 by Mizuno (1999).

The quantitative analysis of amino acids in both fungal mycelia showed differences in their content (Fig. 2). Seven essential amino acids were presented, but their amount were higher in C. sinensis mycelium. The predominant essential amino acid in this fungus was lysine, and threonine was the second. Leucine and threonine were the major constituents of the essential amino acids in the Sch. commune mycelium. The level of nonessential amino acids in Sch. commune was higher compared to $C$. sinensis. Glutamic acid, alanine, lysine and proline were maximal in $C$. sinensis mycelium. The predominance of lysine and alanine in $C$. sinensis mycelium was in agreement with the results reported by Hsu et al. (2002) and Liang et al. (2009). In contrast, Mizuno (1999) noted the predominance of isoleucine in C. sinensis mycelium.
The lipids content of both fungi was low, less than $10 \%$ of dry weight, which is confirmed by other reports (Mizuno, 1999; Liang et al., 2009; Smirnov et al., 2009). Ten fatty acids were detected (Table 4). Smirnov et al. (2009) reported 9 fatty acids (heptadecenoic acid was absent) in $C$. sinensis mycelium grown in a fermenter on the molasses-based medium. There were few significant differences in content of individual fatty acids between fungi species. Palmitic acid (16:0) had the highest content among saturated fatty acids in mycelium of both fungi. Polyunsaturated fatty acids (PUFAs) of $\omega 6$ and $\omega 3$ families were revealed in mycelium. PUFAs are a vital source of energy in our diet. The major fatty acids found were polyunsaturated linoleic

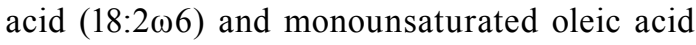

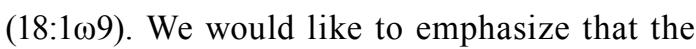
finding of a high content of unsaturated fatty acids and a high percentage of linoleic acid 
in these fungal mycelia is a significant factor which defines these fungi as a health food and useful constituent of our diet.

Thus, amaranth flour meets all the required criteria of the substrate: a readily available free waste product (the waste of $\mathrm{CO}_{2}$-extraction), microbiological purity (Pekhov et al., 1992), high nutritional value and good biological efficiency.

\section{Conclusion}

Amaranth flour contains amino acids, vitamins, microelements for mycelial growth and can be used for cultivation of fungi as an alternative free substrate. This substrate should be consider as a natural, complete medium which could contribute to reducing the cost of biomass production not only for Sch. commune and $C$. sinensis, but for other fungi species. The biomass of Sch. commune and C. sinensis, obtained on this substrate, can be consumed in food industry as a good source of carbohydrates, dietary fiber, nonessential amino and fatty acids. Subsequent research must be devoted to the amaranth flour utilization in submerged culture and to the process of mycelium growing on this substrate for the production of fungal metabolites. The use of amaranth flour expands the boundaries of a waste utilization.

\section{Acknowledgements}

The authors would like to thank Professor A.S. Buchalo for cultures of fungi from IBK Collection.

\section{References}

1. Adejoye O.D., Adebayo-Tayo B.C., Ogunjobi A.A., Afolabi O.O. (2007) Physicochemical studies on Schizophyllum commune (Fries) a Nigerian edible fungus. World Appl. Sci. J. 2: 73-76.

2. Adenipekun C.O., Gbolagade J.S. (2006) Nutritional requirements of Pleurotus florida (Mont.) Singer, a Nigerian mushroom. Pak. J. Nutr. 5: 597-600.

3. AOAC (1990) Official Method 930.04, 978.04, 930.09, 930.04, 930.05, Association of Official Analytical Chemists; Washington, DC, USA.

4. Babitskaya V.G., Bisko N.A., Scherba V.V., Mitropolskay N.Yu. (2003) Some biologically active substances from medicinal mushrooms Ganoderma lucidum (W. Curt.: Fr.) P. Karst. (Agaricomycetideae). Int. J. Med. Mushr. 5: 301-305.

5. Bilay V.I. (1982) Methods experimental mycology. Kiev: Naukova dumka, 550 p. (in Russian).

6. Bolla K., Shaheen S.Z., Vasu K., Charya M.A.S. (2008) Effect of oils on the production of exopolysaccharides and mycelial biomass in submerged culture of Schizophyllum commune. Afr. J. Microbiol. Res. 2: 349-352.

7. Buchalo A.S., Mitropolskay N.Yu., Muchaylova O.B. (2011) Culture collections of mushrooms IBK. Kiev: Alterpres, 100 p. (in Russian).

8. Cha S.H., Lim J.S., Yoon C.S., Koh J.H., Chang H.I., Kim S.W. (2007) Production of mycelia and exo-biopolymer from molasses by Cordyceps sinensis 16 in submerged culture. Biores. Technol. 98: 165-168.

9. Chang H.-L., Chao G.-R., Chen C.-C., Mau J.-L. (2001) Non-volative taste components of Agaricus blazei, Antrodia camphorate and Cordyceps militaris mycelia. Food Chem. 74: 203-207.

10. Chang S.-T., Miles P.G. (2004) Mushrooms. Cultivation, nutritional value, medicinal effect, and environmental impact. London, New York, Washington: CRC Press, 450 p. 
11. Chau C.-F., Wu S.-H. (2006) The development of regulations of Chinese herbal medicines for both medicinal and food uses. Trends Food Sci. Technol. 17: 313-323.

12. Cheung P.C.K. (2008) Nutritional value and health benefits of mushrooms. In: Peter C.K. Cheung (Ed.) Mushrooms as functional food. Hoboken, NJ, USA: Wiley \& Sons, $280 \mathrm{p}$.

13. Chudinov E.G. (1990) Atomic-emission analysis with induction plasma. Results Sci. Technique 2: 3-46 (in Russian).

14. Crisan E.V., Sands A. (1978) Nutritional value. In: Chang S.T., Hayes W.A. (Eds.) The biology and cultivation of edible mushrooms. New York: Academic Press, p.137-165.

15. Dong C.-H., Yao Y.-J. (2005) Nutritional requirements of mycelial growth of Cordyceps sinensis in submerged culture. J. Appl. Microbiol. 99: 483-492.

16. Fasidi I.O., Olorunmaiye K.S. (1994) Studies on the requirements for vegetative growth of Pleurotus tuber-regium (Fr.) Singer, a Nigerian mushroom. Food Chem. 50: 397-401.

17. Folch I., Lees M., Sloan-Statulet G.H.S. (1957) A simple method for isolation and purification of total lipids from animal tissues. J. Biol. Chem. 266: 491-509

18. Garraway O.M., Evans C.R. (1984) Fungi nutrition and physiology. New York: John Willey, $401 \mathrm{p}$.

19. Gbolagade J., Sobowale A., Adejoye D. (2006) Optimization of sub-merged culture conditions for biomass production in Pleurotus florida (mont.) Singer, a Nigerian edible fungus. Afr. J. Biotechnol. 5: 1464-1469.

20. Grangeria C., Heleno S.A., Barros L., Martins A., Ferreira I.C.F.R. (2011) Effects of trophism on nutritional and nutraceutical potencial of wild edible mushrooms. Food Res. Int. 44: 1029-1035.

21. Hsu T.-H., Shiao L.-H., Hsieh C., Chang D.-M. (2002) A comparison of the chemical composition and bioactive ingredients of the Chinese medicinal mushroom DongChongXiaCao, its counterfeit and mimic, and fermented mycelium of Cordyceps sinensis. Food Chem. 78: 463-469.

22. Jonathan S.G., Fasidi I.O. (2001a) Effect of carbon, nitrogen and mineral sources on growth of Psathyerella atroumbonata (Pegler), a Nigerian edible mushroom. Food Chem. 72: 479483.

23. Jonathan S.G., Fasidi I.O. (2001b) Studies on phytohormones, vitamins and mineral element requirements of Lentinus subnudus (Berk) and Schizophyllum commune (Fr.: ex. Fr.) from Nigeria. Food Chem. 75: 303-307.

24. Jonathan S.G. (2002) Vegetative growth requirements and antimicrobial activities of some higher fungi in Nigeria. Ph.D Thesis, University of Ibadan, 268 p.

25. Johnsy G., Kaviyarasan V. (2013) Effect of physic-chemical factors and semi-synthetic media on vegetative growth of Neolentinus kauffmani an edible mushroom from Kanyakumari district. Int. J. Pharma Bio Sci. 4: 469-478.

26. Jwanny E.W., Rashad M.M., Abdu H.M. (1995) Solid-state fermentation of agricultural wastes into food though Pleurotus cultivation. Appl. Bioch. Biotech. 50: 71-78.

27. Kim H.O., Yun J.W. (2005) Acomparative study on the production of exopolysaccharides between two entomopathogenic fungi Cordyceps militaris and Cordyceps sinensis in submerged mycelial cultures. J. Appl. Microbiol. 99: 728-738.

28. Kirk P., Cannon P.F., Minter D.W., Stalpers J.A. (2008) Ainsworth \& Bisby's Dictionary of the Fungi. Wallingford, UK: CAB International, $771 \mathrm{p}$. 
29. Kondentsova V.M. (1994) Selection of riboflavin-binding apoprotein from the albumin of chicken eggs and its use for determination of riboflavin in biological standards. Appl. Biochem. Microbiol. 30: 603-609 (in Russian).

30. Krischenko V.P. (1983) Methods of the estimation of plant production quality. Moscow: Kolos, 192 p. (in Russian).

31. Kumar M.S., Singhal R.S. (2011) Rheological behavior of schizophyllan in fermentation system. Amer. J. Food Technol. 6: 781-789.

32. Kumari M., Survase S.A., Singhal R.S. (2008) Production of schizophyllan using Schizophyllum commune NRCM. Biores. Technol. 99: 1036-1043.

33. Liang C.-H., Huang S.-J., Tsai S.-Y., Lee Y.-L., Kuo H.-C., Wu T.-P., Jian S.-Y., Huang W.-L. (2009) Preparation of novel culinary mushroom products using solid-state fermentation and their taste quality. Int. J. Med. Mush. 11: 141-156.

34. Matušovà K. (2008) The different utilization of amaranth industry. In.: Book of Abstracts of the $5^{\text {th }}$ International Symposium of the European Amaranth Association Slovak Republic: Nitra, p. 22-26.

35. Maziero R., Cavazzoni V., Bononi V.L.R. (1999) Screening of basidiomycetes for the production of exopolysaccharide and biomass in submerged culture. Rev. Microbiol. 30: 77-84.

36. Mizuno T. (1999) Medicinal effects and utilization of Cordyceps (Fr.) Link (Ascomycetes) and Isaria Fr. (Mitosporic fungi) Chinese caterpillar fungi, “Tochukaso" (Review). Int. J. Med. Mush. 1: 251-261.

37. Neelam S., Chennupati S., Singh S. (2013) Comparative studies on growth parameters and physiochemical analysis of Pleurotus ostreatus and Pleurotus florida. Asian J. Plant Sci. Res. 3: 163-169.

38. Osadchenko I.M., Gorlov I.F. (2002) A method of grude fiber determination in biological materials. RU patent 2189760.

39. Ostrovsky Yu.M. (1979) Experimental vitaminology. Minsk: Scitech, 550 p. (in Russian).

40. Pekhov A.V, Kasyanov G.I, Katyuzhanskaya A.N. (1992) $\mathrm{CO}_{2}$-extraction. Overview. Moscow: AgroNIITEIPP, 35 p (in Russian).

41. Pleshkov B.P. (1976) Methods of biochemical analysis of plants. Moscow: Nauka Press, 254 p. (in Russian).

42. Reyes R.G., Graßl W., Rau U. (2009) Coconut water as a novel culture medium for the biotechnological production of schizophyllan. J. Nature Studies 7.

43. Scherba V.V., Babitskaya V.G., Truchonovec V.V., Fomina V.I., Bisko N.A., Mitropolskay N.Yu. (1999) The influence of the cultivation conditions on the chemical composition of medicinal mushrooms Pleurotus ostreatus (Jacq.: Fr.) Kumm. and Lentinus edodes (Berk.) Sing. Int. J. Med. Mush. 1: 181-185.

44. Shu C.-H., Chou P.-F., Hsu I.-C. (2005) Effects of morphology and oxygen supply on schizophyllan formation by Schizophyllum commune using a pellet size controlling bioreactor. J. Chem. Technol. Biotechnol. 80: 1383-1388.

45. Shmalko N.A. (2005) Development of technologies for bakery products with a functional purposeproduct of amaranth seeds. PhD Thesis, Krasnodar, 150 p. (in Russian).

46. Smirnov D.A., Babitskaya V.G., Puchkova T.A., Shcherba V.V., Bisko N.A., Poyedinok N.L. (2009) Some biologically active substances from a mycelium biomass of medicinal 
caterpillar fungus Cordyceps sinensis (Berk.) Sacc. (Ascomycetes). Int. J. Med. Mush. 11: 69-76.

47. Smirnou D., Krcmar M., Prochazkova E. (2011) Chitin-Glucan complex production by Schizophyllum commune submerged cultivation. Polish J. Microbiol. 60: 223-228.

48. Svirskis A. (2003) Investigation of amaranth cultivation and utilization in Lithuania. Agr. Res. 1: 253-264.

49. Tseng Y.-H., Lee Y.-L., Li R.-C., Mau J.-L. (2005) Non-volatile flavour components of Ganoderma tsugae. Food Chem. 90: 409-415.

50. Wasser S.P. (2010) Medicinal mushroom science: history, current status, future trends and unsolved problems. Int. J. Med. Mush. 12: 1-16.

51. Yogita R., Simanta S., Aparna S., Shraddha G., Kamlesh S. (2011) Screening for exopolysaccharide production from basidiomycetes of Chhattisgarh. Current Botany 2: 11-14. 